\title{
Determinants Of Climate Change Adaptation Measures Used By Crop And Livestock Farmers In Southeast Nigeria.
}

\author{
${ }^{1}$ Ifeanyi-obi, C. C, ${ }^{2}$ Asiabaka, C.C and ${ }^{1}$ Adesope, O.M \\ ${ }^{I}$ Department of Agricultural Economics and Extension, University of Port Harcourt. \\ ${ }^{2}$ Department of Agricultural Extension, Federal University of Technology, Owerri.
}

\begin{abstract}
The study identified socio-economic determinants of climate change adaptation measures used by crop and livestock farmers in Southeast Nigeria. Multi-stage sampling technique was used to select one hundred and sixty farmers from the population. Data was collected using structured interview schedule, structured questionnaire, focused group discussion and personal observation while analysis was done using descriptive statistical tools and ordinary least square multiple regression analysis. Result from the analysis showed that out of the 160 respondents that were interviewed in this study, $57 \%$ were male, $86.4 \%$ were above 40 years of age, $95 \%$ were married. It was also shown that $70 \%$ had at least secondary school education, $88.8 \%$ earned monthly income of less than N50, 000 while $84.4 \%$ had above ten years of farming experience. Majority (66.3\%) of the farmers maintained an average household size of 6-10, 82.5\% have farming as their major occupation with $70.6 \%$ having a farm size of less than 1 hectare and $71.2 \%$ practicing mixed farming. Both sales and consumption (68.8\%) were their major aim of production. the major crops cultivated were cassava, yam, maize, vegetables and plantain/banana while the animals reared are poultry birds and goats. The Varimax rotated factor analysis identified eight major adaptation measures used by farmers in the study area. The ordinary least square regression analysis identified seven socio-economic determinants of adaptation measures used by farmers in the study area. Based on the results of the study, vital recommendations that will improve the adaptive capacity of the crop and livestock farmers were made.
\end{abstract}

Keywords: Determinants, climate change, adaptation measures, crop and livestock farmers, southeast Nigeria.

\section{Introduction}

Ifeanyi-obi (2011) described climate change as a canker worm eating up the efforts made by stakeholders in Agricultural sector to enhance Agricultural productivity. According to her, the devastating effects of climate change on agricultural productivity are very significant and as such cannot be neglected. Failure to build up the adaptive capacity of the farmers will surely render the goal of achieving sustainable food security in Nigeria unattainable. Climate change refers to all changes in climate, be it as a result of human activities or natural variations. It is one of the most outstanding challenges facing the global community and as such has been given different definitions by different authors according to their perceptions and the way it affects them. The Intergovernmental Panel on Climate Change (IPCC) (2007) defines climate change as statistically significant variations that persist for an extended period, typically decades or longer, it includes shifts in the frequency and magnitude of sporadic weather events as well as the slow continuous rise in global mean surface temperature. According to them human activities are the main causes of the changes in climate. This, it does in three major ways namely burning of fossil fuels, deforestation and growing world population. This significant variations caused by climate change exert numerous effects on agricultural production which is mainly negative. Researchers have identified some of these negative effects of climate change to be ; changes in the frequency and intensity of droughts, flooding, water shortages, worsening of droughts, worsening soil conditions, desertification, disease and pest outbreaks on crops and livestock, rise in sea level due to melting of ice caps; changes in dates of onset and end of the rainy season; reduced rainfall amounts in some areas and increased rainfall amounts in others, increase in intensity of atmospheric disturbances such as thunderstorms and line squalls (IPCC 2001; ERM 2002; Richards 2003, NEST 2004, Anyanwu 2008; Eboh 2009; Anyadike 2009; Okhimamhe 2009; Ozor 2009; Issa 2009; FAO 2009; Deressa \& Hassan 2009; Ifeanyi-obi 2011; Ifeanyi-obi 2012; Ifeanyi-obi 2012b; Ifeanyi-obi 2013; Ifeanyi-obi 2013b).

NEST (2010) state that mitigation and adaptation are the two principle elements of climate change response. Mitigation refers to measures that may either reduce the increase in greenhouse emissions (abatement) or increase terrestrial storage of carbon (sequestration) while adaptation refers to all the responses to climate change that may be used to reduce vulnerability. Oladipo (2010) stated that although Nigeria, like other developing countries, is not required under the current global climate change negotiations to take on emission reduction commitments, it nevertheless has to adapt to the expected impacts of anticipated climate change. This makes adaptation the major response option to climate change in the nation. 
Climate change adaptation refers to adjustments in practices, processes or structures in response to projected or actual changes in climate (Dixon, 2003), with the goal of maintaining the capacity to deal with current and future changes. Developing effective adaptation options to the numerous extreme weather conditions created by the change in climate has become a major concern of many developing countries particularly Nigeria. Various adaption strategies have been tried by the farmers ranging from planned and unplanned strategies. This includes: In livestock management, the common adaptation strategies employed by producers include; modifying the time of grazing; altering forage and animal species/breeds; altering the integration within mixed livestock and crop systems including the use of adapted forage crops; ensuring adequate water supplies and the using supplementary feeds and concentrate; In crop production, the adaptation options tried include: altering of the timing or location of cropping activities; improved water management through use of technologies to 'harvest' water, conserve soil moisture ( for example, through crop residue retention) and use/transport water more effectively; altering inputs such as crop varieties and species to those with more appropriate thermal time and vernalization; diversifying livelihood strategy to include income from other farming and non farming activities; improving the effectiveness of pest, disease and weed management practices through wider use of integrated pest and pathogen management, development and the use of varieties and species resistant to pests and diseases and maintaining or improving quarantine capabilities and monitoring programs; using climate forecasting tools to reduce production risk.

The fact that Agriculture is practiced across a broad range of climates and environmental conditions makes it necessary for countries to develop an array of adaptation options that will meet the different conditions of the different ecological locations of the nation. It is against this background that this study investigated the socio-economic determinants of climate change adaptation measures used by livestock farmers in Southeast Nigeria.

\section{Objectives of the study.}

The broad objective of this study was to identify the socio-economic determinants of climate change adaptation strategy used by farmers in Southeast Nigeria.

The specific objectives were to:

a. Describe the socio-economic characteristics of farmers in the study area.

b. Identify the adaptation measures used by farmers in the area of study

c. Identify the socio-economic determinants of climate change adaptation measures used by farmers in the study area.

\section{Methodology}

The study was conducted in Southeast Nigeria which is made up of five states namely; Abia, Anambra, Imo, Enugu and Ebonyi state. The climate of Southeast Nigeria according to Mbakwe, (2004) is influenced by the three major air masses namely; the equatorial Maritime, the Equatorial Estuaries and the Tropical continental air masses. The equatorial Maritime originates from the southwest and is warm and very moist, the tropical continental has its origin in the northwest and is warm and very dry while the equatorial estuaries is a cool dry upper air mass which blows from east to west but is occasionally deflated downwards. Rainfall is the key climatic variable and there is a marked alternation of wet and dry seasons in most areas. According to Unamma, (2004), Soil type is predominantly loam with percentages of sandy, loamy and clay soils as 26, 24 and 29 percent in the zone although distribution varied among states. The main cropping systems in the zone is mixed inter cropping system. The number of crops that are mixed-cropped ranged from two to over five with the overall predominant crop combination as yam, maize, cassava, vegetable and egusi. Diseases, weeds and pests constituted the major constraint to increased production. Most of the farmers owned mostly locally manufactured hand tools; the most popular being knives (machetes and cutlasses), hoes of various sizes and shapes, axes, spades, shovels and diggers.

Multi-stage sampling technique was used to select sample for the study. Firstly, two states were randomly selected for this study from the five states that make up the zone. Secondly, two agricultural zones were randomly selected from each of the state giving a total number of four agricultural zones for the study. Thirdly, two circles were randomly selected from each agricultural zone from which twenty respondents was randomly selected for the study giving a total of one hundred and sixty respondents for the study.

Data was collected with the use of interview schedule, structured questionnaire, personal observation and focused group discussion. Adaptation measures were captured using a 34- item statements rated on a fourpoint likert type scale with values of strongly agree $=4$; agree $=3$; disagree $=2$; strongly disagree $=1$. The data collected was analysed using descriptive statistical tools namely; percentages, frequency counts and mean. Adaptation measures used by farmers were analysis using varimax rotated factor analysis. Ordinary least square regression analysis was used to identify the socio-economic determinants of adaptation measures used by farmers in the study area. 
The OLS regression model that was used is implicitly stated as:

$Y_{\mathrm{a}}=\mathrm{f}\left(\mathrm{X}_{1}, \mathrm{X}_{2}, \mathrm{X}_{3}, \mathrm{X}_{4}, \mathrm{X}_{5}, \mathrm{X}_{6}, \mathrm{X}_{7}, \mathrm{X}_{8}, \mathrm{X}_{9}, \mathrm{X}_{10}, \mathrm{X}_{11}, \mathrm{e}\right)$

Where

$\mathrm{Y}_{\mathrm{a}}=$ Index of climate change adaptation measures (based on statements measured on 4 point likert- type rating scale of Strongly Agree $=4$, Agree $=3$, Disagree $=2$, Strongly Disagree $=1$ )

$\mathrm{X}_{1}=$ Gender (dummy variable, male $=1$, female $=0$ )

$\mathrm{X}_{2}=$ Age (years)

$\mathrm{X}_{3}=$ Marital status (dummy variable, single $=0$, married $=1$ )

$\mathrm{X}_{4}=$ level of education (number of years spent in school)

$\mathrm{X}_{5}=$ Farming experience (years)

$\mathrm{X}_{6}=$ Household size (number of persons per household)

$\mathrm{X}_{7}=$ Major occupation (dummy variable, farming $=1$, non farming $=0$ )

$\mathrm{X}_{8}=$ Farm size (Hectares)

$\mathrm{X}_{9}=$ Type of farming activity done $($ mixed farming $=1$, crop production $=2$, livestock management $=3$ )

$\mathrm{X}_{10}=$ Major aim of production (measured on a three point- likert type scale of ; sale $=1$, consumption $=2$, both $=3)$

$\mathrm{X} 11=$ monthly income (Naira)

$\mathrm{e}=$ error term

It is expected a priori that the coefficients of $\mathrm{X}_{1} \mathrm{X}_{2}, \mathrm{X}_{3}, \mathrm{X}_{4}, \mathrm{X}_{5}, \mathrm{X}_{6}, \mathrm{X}_{7}, \mathrm{X}_{8}, \mathrm{X}_{9} \mathrm{X}_{10}, \mathrm{X}_{11}>0$

Four functional forms of the model namely linear, double log, exponential and semi-log was estimated. A lead equation was chosen based on the appropriateness of signs, magnitude of coefficient of multiple determination $\left(\mathrm{R}^{2)}\right.$, statistical significance of the variables and a priori theoretical expectations. The relationship between the dependent and each of the independent variables was examined using the four functional forms: linear, semi-log, exponential and double- log.

Linear: $Y=B_{0}+B_{1} X_{1}+B_{2} X_{2}+B_{3} X_{3}+B_{4} X_{4}+B_{5} X_{5}+B_{6} X_{6}+B_{7} X_{7}+B_{8} X_{8}+B_{9} X_{9}+B_{10} X_{10}+B_{11} X_{11}+e$

Semi-Log: $Y=B_{0}+B_{1} \log X_{1}+B_{2} \log X_{2}+B_{3} \log X_{3}+B_{4} \log X_{4}+B_{5} \log X_{5}+B_{6} \log X_{6}+B_{7} \log X_{7}+B_{8} \log X_{8}+$ $\mathrm{B}_{9} \log \mathrm{X}_{9}+\mathrm{B}_{10} \log \mathrm{X}_{10}+\mathrm{B}_{11} \log \mathrm{X}_{11}+\mathrm{e}$

Exponential: $\log \mathrm{Y}=\mathrm{B}_{0}+\mathrm{B}_{1} \mathrm{X}_{1}+\mathrm{B}_{2} \mathrm{X}_{2}+\mathrm{B}_{3} \mathrm{X}_{3}+\mathrm{B}_{4} \mathrm{X}_{4}+\mathrm{B}_{5} \mathrm{X}_{5}+\mathrm{B}_{6} \mathrm{X}_{6}+\mathrm{B}_{7} \mathrm{X}_{7}+\mathrm{B}_{8} \mathrm{X}_{8}+\mathrm{B}_{9} \mathrm{X}_{9}+\mathrm{B}_{10} \mathrm{X}_{10}+$ $\mathrm{B}_{11} \mathrm{X}_{11}+\mathrm{e}$

Double Log: $\quad \log \mathrm{Y}=\mathrm{B}_{0}+\mathrm{B}_{1} \log \mathrm{X}_{1}+\mathrm{B}_{2} \log \mathrm{X}_{2}+\mathrm{B}_{3} \log \mathrm{X}_{3}+\mathrm{B}_{4} \log \mathrm{X}_{4}+\mathrm{B}_{5} \log \mathrm{X}_{5}+\mathrm{B}_{6} \log \mathrm{X}_{6}+\mathrm{B}_{7} \log \mathrm{X}_{7}+$ $\mathrm{B}_{8} \log \mathrm{X}_{8}+\mathrm{B}_{9} \log \mathrm{X}_{9}+\mathrm{B}_{10} \log \mathrm{X}_{10}+\mathrm{B}_{11} \mathrm{X}_{11}+\mathrm{e}$

$\mathrm{B}_{\mathrm{o}}=$ intercept

$\mathrm{B}_{1}, \mathrm{~B}_{2} \ldots \mathrm{B}_{11}=$ estimated coefficients

$\mathrm{e}=$ error term

\section{Socio-economic characteristic.}

\section{Results and discussion}

Out of the 160 respondents that were interviewed in this study, 57 percent were male revealing that majority of the respondents interviewed in the study were male. It was also revealed that 86.4 percent of the farmers used for the study were above 40 years of age with the mean age found to be 54 years. This could be of advantage to the study as the respondents through their many years of domicility and residence would be better informed about the climatic variations, effects and adaptation measures in the area. It was further shown in Table 1 that majority ( 95 percent) of the farmers were married and have family. Also, majority ( 70 percent) of the farmers had at least secondary school education. The mean number of years spent in school by the respondents was 10 years confirming that majority of the respondents attended secondary school. It could be inferred that farmers of the study area are literate persons who could read and write. This could serve as a capacity to accessing information relating to climate change and adaptation issues as well as adopting new ideas in combating climate change menace. According to Obinne (1991), education is an important factor influencing adoption of farm innovations. Agwu and Anyanwu (1996) also noted that increase in educational status of farmers positively influence adoption of improved technologies and practices.

Data in Table 1 further shows that majority of the respondents ( 88.8 percent) earned a monthly income of less than N50, 000 with only 12.8 percent earning above 50 percent. On the average, respondents earned N21, 000 monthly. This finding reveals that inhabitants of the study area are relatively poor as they live on the average of less than five dollars per day. Only 15.6 percent had farming experience of ten years and below, majority ( 84.4 percent) had above ten years of farming experience.

On the average, the respondents had 23 years of farming experience. This finding indicates that majority of the farmers had long time farming experiences and could have over the years experienced the change in climate as well as the corresponding effects. As a result, they must have acquired wealth of knowledge and effective adaptation measures for cushioning the effects of climate change; as well as identifying obstacles militating against effective adaptation. Thus Mapuno et al (2008) noted that farmers could be in a 
better position to identify challenges and opportunities on climate change based on their indigenous knowledge and experiences. Majority (66.3 percent) of the farmers maintained an average household size of 6-10 persons which is relatively large with an average household size of seven persons. This result is in agreement with the findings of Ozor et. al. (2011) that farmers in southern Nigeria had average household size of 7 persons. Similarly, Adesope et al (2012), Ozor and Nnaji (2010) and Akinnagbe and Ajayi (2010) in their studies reveal that majority of households in rural areas of Nigeria maintain household size of $6-10$ persons. The implication of this is that more family labour will be readily available for farm work since relatively large household size is an obvious advantage in terms of farm labour supply (Sule et.al., 1988). This could probably serve as an insurance against short falls in farm labour supply.

The result also shows that majority of the respondents ( 82.5 percent) have farming as their major occupation hence can be said to be capable of giving information regarding the effects of climate change on agricultural activities and the adaptation options . Only 17.5 percent have all kinds of non-farming activities as their major occupation. On further questioning of the respondents, the non-farming activities indicated includes civil service, trading, transportation business, food vendoring, hair dressing, business center etc. This agrees with the findings of Ifeanyi-Obi et. al. (2011), Enete et. al. (2010) and Nzeh and Eboh (2010) that majority of rural inhabitants have farming as their major occupation. It was further shown that majority $(70.6 \%)$ of the respondents have a farm size of less than 1 hectare while only 18.8 percent had between $1-2$ hectares, 8.75 percent had 3-4 hectares and 1.9 had above 4 hectares. This is in line with the findings of Nzeh and Eboh (2010) which showed that 70 percent of their respondents in a study of the three agricultural zones of Enugu State had access to three hectares of land or below. The implication of higher percentage of respondents having access to less than one hectare of land for farming is the increasing pressure on land as more people depend on fewer hectares of land for farming. This also confirms that majority of the farmers in the area are subsistence farmers. While walking across some of the communities, it was observed that land in the study area was being used for other activities like building of commercial and residential houses, markets, etc. The pressure on land use could add to deforestation which is one of the likely causes and drivers of climate change. It was also shown that 71.2 percent of the respondent indicated mixed farming as their major farming pattern, while 10.0 percent indicated livestock production and the remaining 18.8 percent indicated crop production. The dominance of mixed farming is not surprising as it is a popular farming practice in the country particularly in the southern part of the country. According to most of the farmers, mixed farming is always preferred in order to guard against total crop or animal failure. Also, they indicated that in mixed farming the manure from animals is usually used as cheap organic fertilizers for the crops while the crop residues after harvest serve as animal feed. Ozor et. al. (2011) in line with this result found that mixed farming was the predominant farming practice for farmers in Southern Nigeria. This further implies that farmers actually will be vulnerable to climate change impacts as crop and livestock enterprises are highly susceptible and are affected by climate change impacts.

It was also shown that majority of the respondents ( 68.8 percent) have both sales and consumption as their major aim of production while 10 percent and 16.2 percent indicated sale and consumption respectively as their major aims of production. This shows some of the respondents feed their households from their farm produce thereby reducing the market share of their produce. 


\begin{tabular}{|c|c|c|c|}
\hline VARIABLE & FREQUENCY & PERCENTAGE & MEAN \\
\hline \multicolumn{4}{|l|}{ Gender } \\
\hline Male & 91 & 57 & \\
\hline Female & 69 & 43 & \\
\hline Age & & & 54 \\
\hline $21-40$ & 20 & & \\
\hline $41-60$ & 90 & & \\
\hline $61-80$ & 46 & & \\
\hline Above 80 & 4 & & \\
\hline \multicolumn{4}{|l|}{ Marital status } \\
\hline Single & 8 & & \\
\hline Married & 152 & & \\
\hline No. of years spent in school (Years) & & & 10 \\
\hline 0 (No formal education) & 4 & & \\
\hline $1-6$ & 44 & & \\
\hline $7-13$ & 63 & & \\
\hline $14-19$ & 45 & & \\
\hline Above 19 & 4 & & \\
\hline Monthly income (N) & & & 21,000 \\
\hline$\leq 50,000$ & 142 & & \\
\hline$\overline{5} 1,000-100,000$ & 16 & & \\
\hline $101,000-150,000$ & 2 & & \\
\hline Above 150,000 & 0 & & \\
\hline Farming experience (years) & & & 23 \\
\hline $1-10$ & 25 & & \\
\hline $11-20$ & 59 & & \\
\hline $21-30$ & 44 & & \\
\hline Above 30 & 32 & & \\
\hline Household size & & & 7 \\
\hline $1-5$ & 41 & & \\
\hline $6-10$ & 106 & & \\
\hline $11-15$ & 11 & & \\
\hline $16-20$ & 2 & & \\
\hline \multicolumn{4}{|l|}{ Major occupation } \\
\hline Farming & 132 & 82.5 & \\
\hline Non-farming & 28 & 17.5 & \\
\hline Farm size (Hectare) & & & 2.5 \\
\hline$<1$ & 113 & & \\
\hline $1-2$ & 30 & & \\
\hline $3-4$ & 14 & & \\
\hline Above 4 & 3 & & \\
\hline \multicolumn{4}{|l|}{ Major farming activity } \\
\hline Livestock production & 16 & 10.0 & \\
\hline Crop production & 30 & 18.8 & \\
\hline Mixed farming & 114 & 71.2 & \\
\hline \multicolumn{4}{|l|}{ Major aim of production } \\
\hline Sale & 24 & 15.0 & \\
\hline Consumption & 26 & 16.2 & \\
\hline Both & 110 & 68.8 & \\
\hline
\end{tabular}

Table 1: socio-economic characteristics of crop and livestock farmers in the study area.

\section{Animals reared and crop cultivated by the farmers.}

Table 2 shows animals reared and crops cultivated by the farmers. The result shows that out of the ten crops examined only five are highly cultivated by the respondents with cassava being the most cultivated with a mean of 2.8. Cassava was followed by yam with a mean of 2.6, maize (2.5), vegetables (2.2) and plantain/banana (2.1). Cassava is not only a major staple food but also a major source of farm income for the Nigerian farmers (Nweke, 1996). Adebayo (2006) noted that its high resilience and adaptability to a wide range of ecological conditions has sustained its production through many generations in sub-saharan Africa since it was introduced into the region in $16^{\text {th }}$ century. It is therefore most often described as a hardy crop and may in this sense be the most adaptable crop to climate variations (Enete, 2003). Benhin (2006) reported that one of the strategies which served as an important form of insurance against rainfall variability is increasing diversification by planting crops that are drought tolerant and/or resistant to temperature stresses. Also cassava as a crop could be processed into many products namely garri, fufu, starch, cassava flour, tapioca, animal feed and industrial starch. This peculiar characteristic has been observed to be one of the reasons why most farmers go into cassava production. Yam being the second most cultivated crop is not surprising as yam is known to be a cherished and respected staple food in the south east Nigeria where there is generally an annual celebration in honour of the crop in most part of the zone (Achebe, 2008) . 
It was also shown that poultry and goat was the most reared animal in the study area as they ranked first with a mean score of 2.8 each. This was followed by sheep with a mean of 2.2. cattle ranked last with a mean score of 1.0. This is not surprising as the study area is not a cattle rearing zone in the country.

Table 2: Animals reared and crops cultivated by the farmers.

\begin{tabular}{|c|c|c|c|c|}
\hline Variable & Highly cultivated & Moderately cultivated & Not cultivated & Mean \\
\hline \multicolumn{5}{|l|}{ Crops } \\
\hline Cassava & $135(84.4)$ & 19(11.9) & $6(3.8)$ & 2.8 \\
\hline Yam & $116(72.2)$ & $30(18.8)$ & $14(8.8)$ & 2.6 \\
\hline Maize & $99(61.1)$ & $43(26.6)$ & $18(11.6)$ & 2.5 \\
\hline Cocoyam & $47(29.4)$ & $49(26.6)$ & $63(39.7)$ & 1.9 \\
\hline Rice & $11(6.9)$ & $10(6.6)$ & $139(86.8)$ & 1.2 \\
\hline Cashew & $9(5.6)$ & $20(9.7)$ & $131(85.0)$ & 1.2 \\
\hline Plaintain/Banana & $62(41.9)$ & $52(32.2)$ & $46(25.3)$ & 2.1 \\
\hline Cocoa & $9(5.6)$ & $11(6.9)$ & $140(87.5)$ & 1.2 \\
\hline Vegetables & $73(45.0)$ & $48(29.7)$ & $39(24.7)$ & 2.2 \\
\hline Cowpeas & $10(5.9)$ & $48(17.8)$ & $102(76.3)$ & 1.9 \\
\hline Animals & Highly reared & Moderately reared & Not reared & Mean \\
\hline Sheep & $18(11.3)$ & $16(10.00)$ & $126(78.7)$ & 2.2 \\
\hline Goat & $56(35.0)$ & $28(17.5)$ & $76(47.5)$ & 2.8 \\
\hline Poultry & $64(40.0)$ & $23(14.4)$ & $73(45.6)$ & 2.8 \\
\hline Fish & $9(5.9)$ & $18(11.2)$ & $133(83.1)$ & 1.4 \\
\hline Cattle & $5(3.1)$ & $5(3.1)$ & $150(93.8)$ & 1.0 \\
\hline Rabbit & $2(1.2)$ & $14(8.8)$ & $144(89.9)$ & 1.2 \\
\hline Pig & $6(3.8)$ & $11(6.9)$ & $143(89.3)$ & 1.1 \\
\hline
\end{tabular}

Source: Field survey data, 2012

\section{Climate change adaptation measures used by farmers in Southeast Nigeria.}

The 34 statement of the adaptation measures used by the rural dwellers in the study area were subjected to varimax rotated factor analysis using SPSS version 16. Prior to performing the varimax factor analysis, the suitability of data for factor analysis was assessed. Inspection of the correlation matrix revealed the presence of many coefficients of .3 and above. The Kaiser - Meyer - Olkin value was .752, exceeding the recommended value of .6 [Kaiser - Meyer - Olkin measure of sampling adequacy (KMO)] and Bartlett's Test of sphericity reached statistical significance $\mathrm{P}=.000$ (value is significant at .05 or smaller) supporting the factorability of the correlation matrix.

In determining the number of factors to extract, the total variance explained Table revealed the presence eleven factors with eigen values exceeding 1, explaining $19.5 \%, 8.5 \%, 7.2 \%, 5.9 \%, 4.98 \%, 4.31 \%$, $3.95 \%, 3.5 \%, 3.3 \%, 3.2 \%$ and $3.0 \%$ of the variance respectively. An inspection of the screeplot revealed a break after the eight components. It was then decided to retain eight factors for further investigation. The eight factors explained a total of $57.920 \%$ of the variance.

Table 3 shows the factor analysis procedure with varimax rotation applied to the data yielded an eight dimensional solution. The communalities, which can be regarded as indications of the importance of the variables in the analysis are generally high (above .5). This shows that the variables selected for this study are appropriate and relevant. The eight factors which altogether accounted for 57.920 percent of the total variance in the 34 original variables may be regarded as composite indicators defining adaptation measures used by rural dwellers in the study area.

Based on items loadings of the factor analysis conducted, eight factors were isolated and named. These eight factors therefore represent the major adaptation measures used by respondents in the study area to combat climate change. These factors are improved livestock and crop management practices (factor 1), application of agricultural chemicals and irrigation facilities (factor 2), use of improved and resistant crop and animal species (factor 3), use of information from extension agent and improved land management practices (factor 4), planting of different varieties of crops and varying planting/harvesting dates (factor 5), soil fertility improvement measures (factor 6), use of available credit facilities and joining of cooperative societies (factor 7), portfolio diversification and mixed farming (factor 8 ).

Factor 1 (improved livestock and crop management practices and use of indigenous knowledge) accounted for $19.4 \%$ of the total variance and is without doubt the most important factor. The specific issues that loaded high under this factor include; administration of artificial feed and supplement to livestock to enhance their productivity $(0.569)$, feeding livestock more frequently than before to improve their productivity (0.572), keeping of animals under shade to reduce the heat stress in them (0.557), application of indigenous knowledge in combating climate change $(0.635)$, increase in planting by the riverside $(0.551)$, increase in planting of cover crops to reduce heat stress on crops (.579), weeding more frequently than before to put the increased weed under check (0.617), harvesting early when adverse weather is expected $(0.531)$. 
Factor 2 (application of agricultural chemical and irrigation facilities) accounted for 8.48 percent of the total variance, the issues that amplified this factor include; use of herbicides to reduce the high rate of weed infestation (0.538) and treating of seeds with fungicides before sowing (0.587), using of available irrigation facilities (0.612), application of pesticides to plants (0.621) and use of manual or automated water sprinkling system during hot weather to sprinkle water on livestock to reduce heat stress (0.506). Factor 3 (use of improved crop and animal species) accounted for seven percent of the total variance. The variables that loaded high under this factor include; use of more pest and disease resistant species of crops (0.668), use of more drought tolerant species of crops (0.598) and rearing of disease resistant breed of animals (0.501). Factor 4 (use of information from extension agent and improved land management practices) accounted for 5.9 percent of the total variation. Under this factor, the variables that loaded high were resorting to information from agric extension agents to combat climate change effects $(0.505)$, increase in farm size $(0.636)$ and move to a better farmland (0.521). Factor 5 (planting of different varieties of crops and varying planting dates) accounted for 4.9 percent of the total variance. Three variables loaded high under this factor and they include; use of different planting dates for the crop (0.521), carrying out of early planting of crops $(0.560)$ and planting of different varieties of crops (0.510). Factor 6 (Soil fertility improvement measures) accounted for 4.13 percent of the total variance. The variables that loaded high under this factor include; increase quantity of mulching material (0.560), increase in the use of farm yard manure to improve soil fertility $(0.595)$, increase use of fertilizer (0.629) and increases in the use of fallowing to enable the farmland replenish (.570). Factor 7 (use of available credit and insurance facilities and joining cooperative societies) accounted for 3.95 percent of the total variance. Three variables loaded high under this factor and they include; use of available credit facilities to increase production (0.613), securing of insurance for the enterprise $(0.583)$ and joining cooperative societies $(0.564)$. Factor 8 (portfolio diversification and mixed farming) accounted for 3.5 percent of the total variance. Two variables loaded high under this factor and they include; undertaking of non-farming income generating activities (0.571) and combination of crop and livestock production to increase income $(0.560)$. Onyeneke and Madukwe (2010) found that crop farmer in the southeast rainforest zone of Nigeria resort to portfolio diversification as the major adaptation measure in combating climate change. This calls for urgent consideration by all stakeholders and immediate action. Farmers should be taught or exposed to adaptation measures that improve their crop and livestock production rather than abandoning it for other non-farming income generating activities. Climate change should not be allowed to extinct the agricultural sector rather the agricultural sector should evolved ways of adapting to the effects of climate change.

Table 3: Varimax rotated factor analysis of adaptation measures used by farmers in Southeast Nigeria

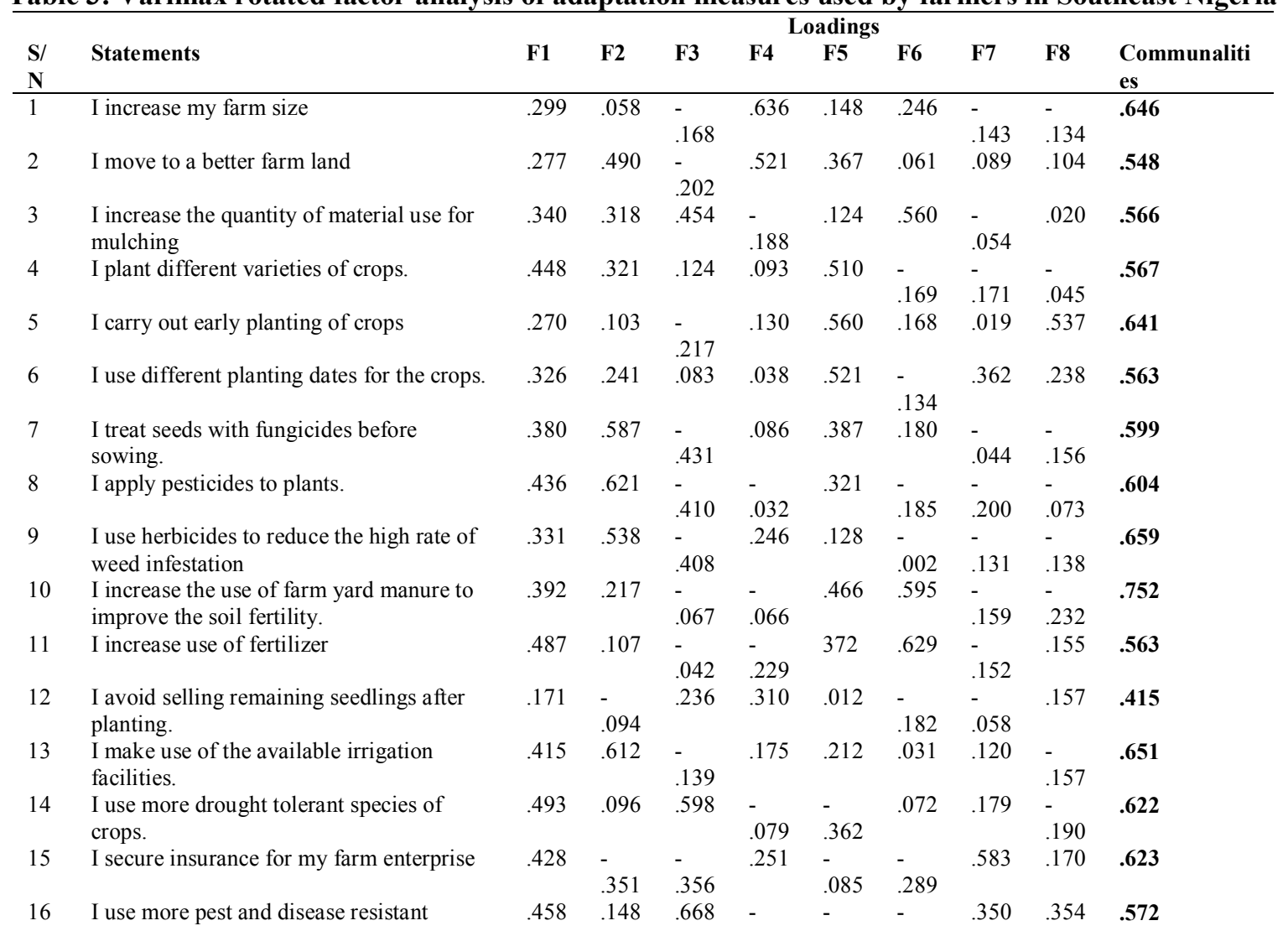




\begin{tabular}{|c|c|c|c|c|c|c|c|c|c|c|}
\hline & species of crops & & & & .127 & .148 & .099 & & & \\
\hline 17 & $\begin{array}{l}\text { I harvest early when adverse dry weather } \\
\text { is expected. }\end{array}$ & .531 & .266 & .152 & -143 & .029 & .016 & .282 & .047 & .579 \\
\hline 18 & $\begin{array}{l}\text { I undertake other non-farm income } \\
\text { generating activities }\end{array}$ & .477 & .042 & .162 & -408 & - & .026 & -146 & .571 & .568 \\
\hline 19 & $\begin{array}{l}\text { I resort to information from agric } \\
\text { extension agents to combat climate change } \\
\text { effects. }\end{array}$ & .379 & $\begin{array}{l}- \\
.034\end{array}$ & .003 & .505 & .302 & $\begin{array}{l}- \\
.025\end{array}$ & $\begin{array}{l}- \\
.164\end{array}$ & .182 & .552 \\
\hline 20 & $\begin{array}{l}\text { I use available credit facilities to increase } \\
\text { my production }\end{array}$ & .333 & .051 & -183 & -215 & -120 & -346 & 613 & -.046 & .619 \\
\hline 21 & $\begin{array}{l}\text { I increase reliance on family labour to } \\
\text { reduce cost of production. }\end{array}$ & .296 & .098 & .379 & -.039 & .252 &.- &. & -.025 & .476 \\
\hline 22 & $\begin{array}{l}\text { I weed more frequently than before to put } \\
\text { the increased weed under check. }\end{array}$ & .617 & .156 & .278 & .117 & .054 & -.134 & .419 & .026 & .554 \\
\hline 23 & $\begin{array}{l}\text { I increase the planting of cover crops to } \\
\text { reduce heat stress on crops. }\end{array}$ & .579 & .022 & .407 & .211 & - & -328 & .273 & -162 & .678 \\
\hline 24 & $\begin{array}{l}\text { I increase the use of fallowing to enable } \\
\text { my farm land replenish. }\end{array}$ & .398 & .338 & .336 & .240 & -139 & .570 & .281 & -111 & .559 \\
\hline 25 & I increase planting by the river side. & .551 & -452 & -.046 & .243 & -186 & -178 & .003 & .240 & .692 \\
\hline 26 & $\begin{array}{l}\text { I combine crop production and livestock } \\
\text { management to increase my income. }\end{array}$ & .321 & $\begin{array}{l}- \\
.017\end{array}$ & .207 & .180 & .242 & .341 & .049 & .560 & .595 \\
\hline 27 & $\begin{array}{l}\text { I keep animals under shade to reduce the } \\
\text { heat stress in them. }\end{array}$ & .557 & -121 & .475 & .147 & .205 & .078 & -225 & .219 & .640 \\
\hline 28 & I rear disease resistant breed of animals & .413 & -418 & .501 & -.064 & .261 & .328 & .047 & .334 & .620 \\
\hline 29 & I rear heat tolerant breed of livestock & .476 & $\begin{array}{l}- \\
.468\end{array}$ & .488 & .075 & .223 & -.060 & -176 & .498 & .632 \\
\hline 30 & $\begin{array}{l}\text { I use manual or automated water } \\
\text { sprinkling system during hot weather to } \\
\text { sprinkle water on livestock to reduce heat } \\
\text { stress. }\end{array}$ & .381 & .506 & $\begin{array}{l}- \\
.072\end{array}$ & .034 & .319 & .010 & .303 & .010 & .635 \\
\hline 31 & $\begin{array}{l}\text { I feed livestocks more frequently than } \\
\text { before to improve their productivity. }\end{array}$ & .572 & -316 & .056 & -133 & 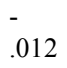 & .119 & .085 & .090 & .477 \\
\hline 32 & $\begin{array}{l}\text { I administer artificial feed supplements to } \\
\text { livestock to enhance their productivity. }\end{array}$ & .569 & -332 & -280 & -.003 &.- & .342 & .155 & .123 & .665 \\
\hline 33 & $\begin{array}{l}\text { I join cooperative societies in order to } \\
\text { fight the effects of climate change more } \\
\text { vigorously }\end{array}$ & .341 & - & -212 & -.235 & .165 & - & .564 & $\begin{array}{l}- \\
.071\end{array}$ & .595 \\
\hline 34 & $\begin{array}{l}\text { I apply indigenous knowledge in } \\
\text { combating climate change effects. }\end{array}$ & .653 & .180 & -.052 & -372 & .265 & -.042 & .328 & -264 & .628 \\
\hline & Eigen value & $\begin{array}{l}6.62 \\
2\end{array}$ & $\begin{array}{l}2.88 \\
5\end{array}$ & $\begin{array}{l}2.46 \\
2\end{array}$ & $\begin{array}{l}2.01 \\
3\end{array}$ & $\begin{array}{l}1.69 \\
5\end{array}$ & $\begin{array}{l}1.46 \\
9\end{array}$ & $\begin{array}{l}1.34 \\
4\end{array}$ & $\begin{array}{l}1.20 \\
3\end{array}$ & \\
\hline & $\%$ of variance & $\begin{array}{l}19.4 \\
76\end{array}$ & $\begin{array}{l}8.48 \\
5\end{array}$ & $\begin{array}{l}7.24 \\
1\end{array}$ & $\begin{array}{l}5.92 \\
0\end{array}$ & $\begin{array}{l}4.98 \\
6\end{array}$ & $\begin{array}{l}4.31 \\
9\end{array}$ & $\begin{array}{l}3.95 \\
4\end{array}$ & $\begin{array}{l}3.53 \\
9\end{array}$ & \\
\hline & Cumulative $\%$ & $\begin{array}{l}19.4 \\
76 \\
\end{array}$ & $\begin{array}{l}27.9 \\
61 \\
\end{array}$ & $\begin{array}{l}35.2 \\
02 \\
\end{array}$ & $\begin{array}{l}41.1 \\
22 \\
\end{array}$ & $\begin{array}{l}46.1 \\
08 \\
\end{array}$ & $\begin{array}{l}50.4 \\
28 \\
\end{array}$ & $\begin{array}{l}54.3 \\
82 \\
\end{array}$ & $\begin{array}{l}57.9 \\
20 \\
\end{array}$ & \\
\hline
\end{tabular}

Source: Field survey, 2012

\section{Socio-economic determinants of climate change adaptation option used by farmers in the study area.}

Ordinary least square multiple regression analysis was applied in identifying these socio-economic determinants of climate change adaptation measures used by farmers in the study area. Based on the appropriateness of signs, number of significant variables and magnitude of $\mathrm{R}^{2}$, the Semi-linear model functional form was chosen as lead equation. This was confirmed by the F-ratio value of 15.51 which was significant at both 0.05 and 0.01 probability level and further confirmed by a p-value of 0.000 . The result of the ordinary least square multiple regression analysis in Table 4 reveals that $42.1 \%$ of the variation in adaptation measures used by the farmers in the study area could be explained by their socio-economic characteristics in the equation.

The result indicates that seven of the ten independent variables (years of education, major occupation, farming experience, major farm activity, farm size and monthly income) correlated positively and significantly with adaptation measures used by farmers in the study. The coefficient of determination monthly income correlated positively with rural dwellers level of awareness of climate change with a t-value of 2.268 which was significant at 0.05 level. Number of years in school correlated positively with adaptation measures with a t-value of 5.64 at 0.01 probability level. This could imply that those who spent more years in school may understand and adopt better adaptation measures. This is as a result of the fact that those who had spent more years in school are better informed and enlightened to be able to identify and adopt better adaptation measures. Major occupation also correlated positively with adaptation measures with a t-value of 6.78 at 0.01 probability level. This is not surprising as those who have agricultural activity as their major occupation are more likely to be interested in issues of climate change particularly adaption to the menace. Farming experience was also found to positively correlate with level of awareness of climate change. This could imply that the higher the years of 
farming the more knowledgeable and experienced the farmers become in climate change adaptation issues. The type of farming activity done correlated positively with level of awareness. The implication of this finding is that the type of farming activity done by the farmers determines the adaptation option used by the farmers. Farmers who indulge in both livestock management and crop production (mixed farming) will have to adopt more adaptation measures that can address both the livestock and crop production needs as regards climate change.

The Table also revealed that farm size correlated positively with the farmers adaptation measures. Majority of farmers who maintain large size of farm land are known to be commercial farmers. Commercial farmers are most likely to be committed to agricultural activity as that could be their major source of income, therefore one may not be surprised if they are able to identify promptly any change in the climate situation of their environment and as well adapt to the changes promptly. Also those who have larger farms are affected more by the change in climate as a result of their having more crops and animals which are vulnerable to climate change effects. It is therefore expected that they should be more involved in issues of climate change adaptation.

Also major aim of production and marital status were seen to play a major role in the adaptation measures used by the farmers. This is not surprising as farmers in the study area indicated both sale and consumption to be their major aim of production. This is to say that agricultural activity serve as both source of food for their household as well as source of income. Therefore, it is expected that these people will always be at alert concerning any change in agricultural production as it is their major source of income and household food supply. As regards marital status, one can say that those who are married have more financial responsibility than the single ones. Since farming is their major source of income, it is expected that any issue affecting farming must be seriously taken and mitigation and adaptation measures sought for without delay.

Apata (2008) similarly identified farming experience, farm size, educational status and access to extension and credit facilities to significantly and positively affect adaptation to climate change while household size was found to significantly and negatively affect adaptation.

Table 4: Ordinary least square regression analysis of socio-economic determinants of climate change adaptation measures used by farmers in the study area.

\begin{tabular}{|c|c|c|c|c|c|}
\hline $\mathbf{S} / \mathbf{N}$ & Variable & Linear & Semi log & $\begin{array}{l}\text { Double } \\
\text { Log }\end{array}$ & Exponential \\
\hline 1. & Constant & $\begin{array}{l}69.910 \\
(2.992)^{* *}\end{array}$ & $\begin{array}{l}94.831 \\
(9.354)^{* *}\end{array}$ & $\begin{array}{l}1.860 \\
(17.725)^{* *}\end{array}$ & $\begin{array}{l}1.974 \\
(43.333) * *\end{array}$ \\
\hline 2. & Gender & $\begin{array}{l}-1.324 \\
(-.560)\end{array}$ & $\begin{array}{l}-.040 \\
(-.420)\end{array}$ & $\begin{array}{l}-.039 \\
(-.407)\end{array}$ & $\begin{array}{l}-.055 \\
(-.589)\end{array}$ \\
\hline 3. & Age & $\begin{array}{l}-.29 \\
(-.273)\end{array}$ & $\begin{array}{l}-.054 \\
(-.494)\end{array}$ & $\begin{array}{l}-.050 \\
(-.454)\end{array}$ & $\begin{array}{l}-.030 \\
(-.281)\end{array}$ \\
\hline 4. & Marital status & $\begin{array}{l}.178 \\
(2.076)^{*}\end{array}$ & $\begin{array}{l}.185 \\
(2.056)^{*}\end{array}$ & $\begin{array}{l}.164 \\
(1.821)\end{array}$ & $\begin{array}{l}.159 \\
(1.846)\end{array}$ \\
\hline 5. & Years of Education & $\begin{array}{l}.254 \\
(2.822)^{* *}\end{array}$ & $\begin{array}{l}.356 \\
(5.64) * *\end{array}$ & $\begin{array}{l}.136 \\
(1.396)\end{array}$ & $\begin{array}{l}.253 \\
(2.793)^{* *}\end{array}$ \\
\hline 6. & Monthly income & $\begin{array}{l}.025 \\
(.294)\end{array}$ & $\begin{array}{l}.218 \\
(2.267)^{*}\end{array}$ & $\begin{array}{l}.218 \\
(2.254)^{*}\end{array}$ & $\begin{array}{l}.013 \\
(.159)\end{array}$ \\
\hline 7. & Years farmed & $\begin{array}{l}0.239 \\
(3.11)^{* *}\end{array}$ & $\begin{array}{l}0.52 \\
(3.98)^{* *}\end{array}$ & $\begin{array}{l}0.28 \\
(2.969) * *\end{array}$ & $\begin{array}{l}0.24 \\
(2.87)^{* *}\end{array}$ \\
\hline 8. & Household size & $\begin{array}{l}-.072 \\
(-.878)\end{array}$ & $\begin{array}{l}-.040 \\
(-.478)\end{array}$ & $\begin{array}{l}-.034 \\
(-.413)\end{array}$ & $\begin{array}{l}-.062 \\
(-.756)\end{array}$ \\
\hline 9. & Major occupation & $\begin{array}{l}0.134 \\
(3.91)^{* *}\end{array}$ & $\begin{array}{l}4.45 \\
(6.78)^{* *}\end{array}$ & $\begin{array}{l}1.32 \\
(2.61)^{* *}\end{array}$ & $\begin{array}{l}0.45 \\
(2.32)^{* *}\end{array}$ \\
\hline 10. & Farm size & $\begin{array}{l}0.475 \\
(3.09)^{* *}\end{array}$ & $\begin{array}{l}0.49 \\
(3.064)^{* *}\end{array}$ & $\begin{array}{l}0.312 \\
(2.68)^{* *}\end{array}$ & $\begin{array}{l}2.917 \\
(2.63)^{* *}\end{array}$ \\
\hline 11. & Major farming activity & $\begin{array}{l}-.133 \\
(-1.613)\end{array}$ & $\begin{array}{l}-.204 \\
(-2.241)^{*}\end{array}$ & $\begin{array}{l}-.198 \\
(-2.331)^{*}\end{array}$ & $\begin{array}{l}-.047 \\
(-1.558)\end{array}$ \\
\hline 12. & Major aim of production & $\begin{array}{l}-.043 \\
(-.523)\end{array}$ & $\begin{array}{l}-.035 \\
(-.414)\end{array}$ & $\begin{array}{l}-.037 \\
(-.435)\end{array}$ & $\begin{array}{l}-.049 \\
(-.588)\end{array}$ \\
\hline & $\mathbf{R}^{2}$ & 0.354 & 0.421 & 0.312 & 0.311 \\
\hline & F-Statistics (F-Value) & 13.54 & 15.51 & 10.23 & 10.11 \\
\hline & Pro & 0.001 & 0.000 & 0.002 & 0.003 \\
\hline
\end{tabular}

Figures in the first row are regression Coefficients, t-ratios are in parentheses

$*$ t-ratios significant at 0.05 probability level, $* *$ t-ratios significant at 0.01 probability level

Source: computed from survey data, 2012

\section{Conclusion and recommendation}

The study identified the socio-economic determinants of climate change adaptation option used by farmers in southeast Nigeria. Based on the findings of the study, the study concludes that the major determinants of adaptation measures used by farmers in the study area are: years of education, monthly income, marital 
status, number of years farmed, major occupation, farm size and farming activity done. It was recommended that farmers should be encouraged and helped to form cooperatives to enable them pool resources as this will help them fight more vigorously the challenges and threats of climate change events. Also, government should through the ADP and other effective means make the procurement of improved farm inputs (pest/disease and drought resistant seedlings, fertilizer, e.t.c) more accessible to farmers since it is one of the major adaptation measures used by famers in the area. More planned adaptation measures should also be introduced into the area to boost farmer's adaptive capacity. Furthermore, more favourable land policies towards agricultural production should be put in place to enable farmers increase their farm lands.

\section{References}

[1]. Achebe, C. (2008) Things fall apart. Pearson education limited. Edinburgh gate, harlow essex, CM20 2JE. England

[2]. Adebayo, K. (2006). Dynamics of the Technology Adoption Process in Rural- based Cassava Processing Systems in Southwest Nigeria. International Foundation for Science, Sweden.

[3]. Adesope, O.M, Ifeanyi-Obi, C.C, Ugwuja, V.C and Nwakwasi R. (2012). Effect of malaria on the farm income of rural households in Ekeremor Local Government Area of Bayelsa State. International Journal of Agrcicultural Economics Management. Vol. 2(1), pp. $27-36$.

[4]. Agwu E. A and Anyanwu, A.C (1996). Socio-cultural and Environmental Constraints in Implementing the NALDA programme in south eastern Nigeria. A case study of Abia and Enugu State. Journal of Agriculture and Education. Vol. 2. pp 68 - 72.

[5]. Akinnagbe O.M and Ajayi A.R (2010). Assessment of farmer's benefits derived from Olam Organization sustainable cocoa production extension activities in Ondo State. Journal of Agricultural Extension. Vol. 14(1), June 2010.

[6]. Apata, T.G (2008). Effects of global climate change on Nigeria agriculture; an empirical analysis. CBN Journal of applied statistics Vol 2 (1), 2008

[7]. Benhin, J. K. A (2006). Climate Change and South African Agriculture: Impacts and Adaptation options. Centre for Environmental Economics and Policy for Africa (CEEPA). Discussion Paper. No. 21 CEEPA, University of Pretoria, South Africa.

[8]. Enete A. A (2003). Resource use, marketing and diversification decision in Cassava Producing Household of Sub-Saharan Africa. A Ph.D. Dissertation Presented to the Department of Agricultural Economics, Catholic University of Lovain, Belguim.

[9]. Enete, A.A., Madu, I.I., Mojekwu,J.C., Onyeukwu, A.N., Onwubuya, E.A.,and Eze, F (2010). Indigenous Agricultural Adaptation to climate change: study of Imo and Enugu State in southeast Nigeria. Africa Technology Policy studies Network working paper. Series No. 53

[10]. Ifeanyi-obi, C.C., Asiabaka, C.C., Adesope, O.M. and Issa, F.O. (2011). Inhabitants perception of climate change, effects and adaptation strategies in Etche Local Government Area of Rivers State, Nigeria. Global journal of Applied Agricultural research. Vol. 1(1). Pp 57-64.

[11]. Intergovernmental panel on climate change (IPCC) (2007). Impact, Adaptation and vulnerability. Contribution of Working Group 1 of the intergovernmental panel on climate change to the Third Assessment Report of IPCC. London : Cambridge University Press.

[12]. Mapuno, P, Chiwo, R., Mtambanengwe, F., Adjei-Nsiahs, Baijukya, F., Maria, R., Mvula, A., and Gilla, K. (2008). Farmers perception leads experimentation and learning (Charese - J, Hampson K., Salm M., Schoubroeck F., Roem, W., Rooyakkers, and Walsum E., (eds). Dealing with climate change. LEISA, 2008 Pp $28-29$.

[13]. Nweke, F.I (1996) Cassava: A cash crop in Africa. COSCA working paper. No. 14, COSCA, IITA, Ibadan, Nigeria.

[14]. Nzeh E.C and Eboh O.R. (2010). Technological Challenges of Climate Change Adaptation in Nigeria: Insights from Enugu State. African Technology Policy Studies Network working paper. Series No 52.

[15]. Obinne, C.P (1991). Adoption of improved cassava production technologies by small-scale farmers in Bendel State. Journal of Agricultural Science and Technology. Vol. 1(1): pp.12-15.

[16]. Onyeneke, R.U and Madukwe, D.K (2010). Adaptation measures by crop farmers in the Southeast rainforest zone of Nigeria to climate change. Science World Journal, Vol $\quad 5(1) 2010$.

[17]. Ozor, N. (2009). Understanding climate change. Implications for Nigerian Agriculture, policy and Extension. Paper presented at the National conference on climate change and the Nigeria Environment. Organized by the Department of geography, university of Nigeria, Nsukka, 29 June-2nd July.

[18]. Ozor, M., Madukwe, M.C., Enete, A.A., Amaechina, E.C., Onokala, P., Eboh, E.C., Ujah, O. and Garforth, C.J. (2010). Barriers to climate change adaptation among farming households of Southern Nigeria. Journal of Agricultural Extension. Vol. 14(1). Pp. 114- 124 .

[19]. Unamma, R.P.A, Onwudike, O.C, Uwaegbute, A.C, Edeoga, H.O and Nwosu, A.C (2004). Linkage strategy for sustainable Agriculture in Nigeria. Research-Extension-Farmer-Input-Linkage system (REFILS). Micheal Okpara University of Agriculture, Umudike. 